\title{
The Jobs Impact of the USA New Green Deal
}

\author{
Roger H. Bezdek \\ Management Information Services, Inc., Washington DC, USA \\ Email: rbezdek@misi-net.com
}

How to cite this paper: Bezdek, R. H. (2020). The Jobs Impact of the USA New Green Deal. American Journal of Industrial and Business Management, 10, 1085-1106. https://doi.org/10.4236/ajibm.2020.106072

Received: April 21, 2020

Accepted: June 7, 2020

Published: June 10, 2020

Copyright (c) 2020 by author(s) and Scientific Research Publishing Inc. This work is licensed under the Creative Commons Attribution International License (CC BY 4.0).

http://creativecommons.org/licenses/by/4.0/

\begin{abstract}
In the USA and other nations there is intense interest in the Green New Deal (GND) and its jobs implications. However, there has not been a comprehensive analysis of the potential jobs impacts of the GND. This paper remedies this deficiency and provides estimates of the jobs likely to be created by the GND in the USA, including jobs in the manufacturing sector. We first estimate the current size of the green industry in the USA and find that it totals $\$ 640$ billion in industry sales and 7.8 million jobs. We estimate that the GND would generate more than 18.3 additional million jobs throughout the economy. Of these, 2.25 million would be green manufacturing jobs, and these are disaggregated by major industrial components ( 2 and 3 digit NAICS Code). The GND jobs are concentrated within a number of sectors, including manufacturing and professional, information, and scientific and technical services. Thus, not only is the relationship between the GND and jobs positive, but the types of jobs created are disproportionately scientific, professional, technical, high-skilled, manufacturing, and high-wage jobs-the very types of jobs highly sought after.
\end{abstract}

\section{Keywords}

Climate Change Jobs, Environmental Jobs, Green New Deal Jobs, Green Manufacturing Jobs, Sustainable Jobs

\section{Introduction}

The Green New Deal (GND) is a proposed package of USA legislation designed to address climate change, economic inequality, and other issues. The name is derived from the New Deal, a set of social and economic reforms and public works projects undertaken by USA President Franklin Roosevelt in response to the Great Depression of the 1930s. The GND combines Roosevelt's economic approach with contemporary proposals involving environmental programs, renewable energy, and energy efficiency, and its estimated costs run well into the 
trillions of dollars. In recent years, various proposals for a "Green New Deal" have arisen both in the USA and internationally.

There is currently much controversy in the USA concerning the GND, and it is featuring in the 2020 Presidential election. Democrats have been advocating it as a much needed economic and job stimulus and as a way to facilitate recovery from the current environment where job losses and unemployment are at record levels not seen since the Great Depression. On the other hand, Republicans contend that the GND would ruin the economy and destroy jobs.

There is thus intense interest in the jobs impact of the GND-especially the impact on manufacturing jobs. Until now, GND jobs impacts have not been comprehensively estimated and analyzed in detail. This paper provides this important information for the USA.

\section{Review of Previous Research}

There have been a number of studies of USA green jobs and GND jobs over the past two decades. Here we summarize the major ones.

In 1999, Bernow, Cory, Dougherty, Duckworth, Kartha, and Ruth examined the impact of implementing policies designed to bring the U.S. in compliance with the Kyoto Protocol (Bernow, Cory, Dougherty, Duckworth, Kartha, \& Ruth, 1999). They found that the U.S. could reduce its carbon emissions to its Kyoto target and that the prescribed policies would produce net economic savings. They estimated that by 2010 almost 900,000 net new jobs would be created, relative to the baseline.

In 2002, University of Illinois research staff analyzed the Midwest's Clean Energy Development Plan, which advocated energy efficient technologies and development of renewable energy resources, especially wind power and biomass energy (Regional Economics Application Laboratory, 2002). They estimated that implementing the plan would create more than 200,000 new jobs across the 10-state Midwest region by 2020 .

In 2004 Barret and Heorner assessed the impact of policies designed to provide steady increases in energy efficiency and reductions in carbon emissions, while improving overall economic efficiency (Barret \& Heorner, 2004). They analyzed the impact of these policies and estimated that an additional 660,000 net jobs would be created in 2010 and 1.4 million in 2020. This would increase employment in the service sector and reduce the rate of decline in manufacturing employment.

In 2004, the New Apollo Initiative proposed an economic development plan for the USA based on diversifying energy sources, making the U.S. less dependent on foreign oil, investing in green industries, promoting energy efficient buildings, and investing in cities and communities (Apollo Alliance, 2004). It estimated that an annual $\$ 30$ billion investment for 10 years would add more than 3.3 million jobs to the economy and stimulate \$1.4 trillion in new GDP.

In 2004, the Union of Concerned Scientists analyzed the effects of imple- 
menting a national renewable electricity standard (RES) that would require electric utilities to supply a set percentage of their electricity from renewable sources (Union of Concerned Scientists, 2004). It found that under a national RES of $20 \%$ by 2020 , the USA would increase its total renewable power capacity 11 -fold and create more than 355,000 new jobs.

In 2008, Bezdek, Wendling, and DiPerna analyzed the relationship between environmental protection, the economy, and jobs in the USA (Bezdek, Wendling, \& DiPerna, 2008). They estimated the size of the USA environmental industry and the numbers of environment-related jobs at the national level and in the states of Florida, Michigan, Minnesota, North Carolina, Ohio, and Wisconsin. They found that, contrary to conventional wisdom, environmental protection, economic growth, and jobs creation are complementary and compatible: Investments in environmental protection create jobs and displace jobs, but the net effect on employment is positive. They found that environmental protection has grown rapidly to become a major sales-generating, job-creating industry- $\$ 300$ billion/yr. and 5 million jobs in 2003.

In 2011, the Georgetown University Center on Education and the Workforce (GUCEW) found that there was broad consensus on issues related to the green economy (Georgetown University Center on Education and the Workforce, 2011). First, the green economy is still nascent and makes up a small portion of the USA economy and total employment: Between $1 \%$ and $2 \%$ of total jobs; while at the state level, employment share goes as high as $5 \%$. Due to its emerging status, it is difficult to project employment demand and know exactly where green jobs are going to be, what look like, what industries and occupations they will be in, and what types of skills and training will be needed to fill them. Further, it is impossible to predict how the green economy will change the current workforce in the long-term, because many potential jobs, skills, and industries have yet to emerge. Unforeseen technologies could play a decisive role in development of the green economy. There is also broad agreement there is occurring a "greening" of the economy; that green jobs are fundamentally the same as traditional jobs but may require an extra layer of skills/training; and that there is no good way to get a precise count of green jobs.

In 2011, the Brookings Institution estimated that the clean economy employed 2.7 million workers, encompassing numerous jobs spread across many industries (Brookings Institution, 2011). Though modest in size, the clean economy employs more workers than the fossil fuel industry, is larger than bioscience, but remains smaller than the IT-producing sectors. Most clean economy jobs are in mature segments that cover a wide swath of activities including manufacturing and the provision of public services such as wastewater and mass transit. A smaller portion of the clean economy encompasses newer segments that respond to energy-related challenges. Brooking found that:

- The clean economy grew more slowly than the national economy between 2003 and 2010. 
- The clean economy is manufacturing and export intensive-26\% of all clean economy jobs are in manufacturing, compared to just $9 \%$ in the broader economy.

- The clean economy offers more opportunities and better pay for low- and middle-skilled workers than the national economy as a whole.

- A disproportionate portion of clean economy jobs are staffed by workers with relatively little formal education in moderately well-paying "green collar" occupations.

In 2013 Bruyère and Filiberto found that the percentage of total employment associated with the green economy has increased in the USA, presenting job opportunities in many emerging fields (Bruyère \& Filiberto, 2013). As green employment options increase, people with disabilities should have equitable employment opportunities in this growth sector. A focused strategy to train and engage people with disabilities in the green economy can provide a talented and untapped segment of the USA workforce and a greater opportunity to participate in this growing sector than previously realized.

In 2014, Bezdek and Wendling estimated the economic and jobs impact of the USA displacing 1.2 billion tons of carbon emissions annually by 2030 using energy efficiency and renewable energy (Bezdek \& Wendling, 2014b). They assessed the technologies deployed, their costs, and the necessary time frames. They then estimated the job impacts of the policy and found that it will generate more than 4.5 million net jobs. They disaggregated the jobs created by industry, occupation, skill, and salary, and discussed the policy implications of these findings. Their major conclusion was that climate mitigation initiatives can be a major net job creator for the USA.

In 2015, the California Center for Jobs and the Economy found that green jobs constitute a small portion of total jobs, and estimates place green jobs at around $2 \%$ of the state's total (California Center for Jobs and the Economy, 2015). And while green jobs will contribute to resolving the state's job creation challenges, they are not at a scale where they will do it alone. Policies addressing the competitiveness of the other $98 \%$ of the state's jobs are needed as well. All of the estimates rely in part on redefining many traditional jobs as "green" jobs. This includes reclassification of government jobs such as in public transit and waste management and treatment. Many green jobs rely on tax subsidies or cost increases on products such as electricity or cars. While some green products are economic and some rely on market pricing based on green branding, many green jobs identified continue to rely on subsidies and regulatory fiats. Most green job estimates have been prepared in defense of regulatory programs, but account only for the jobs created as the regulations have been promulgated. They did not address the added costs on traditional job sectors to purchase the green goods and services when required under regulation, nor did they address jobs lost in this process.

Between 2016 and 2020, the U.S. Department of Energy (DOE) annually pub- 
lished the U.S. Energy and Employment Report (USEER) (National Association of State Energy Officials and the Energy Futures Initiative, 2020). The USEER sought to provide consistent definitions and quantification of energy jobs in the economy. It addressed several gaps in energy employment data, including: business activities essential to the operation of traditional energy companies and utilities classified within the activities of other sectors; jobs associated with the production of renewable energy; jobs associated with energy efficiency. The 2018 USEER found that in 2016 there were 800,000 workers working in low carbon emission energy generation technology, and 2.35 million working in some part to design, manufacture, or distribute energy efficient products. The USEER relied on surveys to identify energy-related employment within subsectors of broader industries. However, there are deficiencies in the USEER. For example,

- The jobs figures are supposed to refer only to direct employment and not to indirect employment or induced employment. However, the reports' employment figures do include some indirect jobs, although it is not clear how many.

- It is not clear what "job" concept USEER utilizes. There are repeated references to "employment," "workforce," "jobs," and "net jobs." Further, these concepts are sometimes used interchangeably in a confusing manner.

- The methodologies used in the annual USEERs are different, and it is thus, it is difficult to estimate serial employment trends.

- It virtually ignores important categories of renewable energy, such as fuel cells and hydrogen.

In 2016, Bezdek forecast the sustainable energy industries in the USA to 2030 (Bezdek, 2016). He developed a rigorous definition of the sustainable energy industries, estimated their current sizes and composition, including technology, sales, tax revenues generated, jobs, occupations, and skills, and forecast their growth to 2030 under three scenarios for the USA and Ohio: 1) a "business as usual" scenario that assumes no change in policy, 2) a Moderate Scenario that assumes that various moderate, incremental Federal and state sustainable energy initiatives are enacted over next two decades, and 3) an Advanced Scenario that "pushes the envelope" on the sustainable energy industries possible from current or impending technologies. He found that the sustainable energy industries create a variety of high-paying jobs, many of which take advantage of manufacturing skills currently going unused as manufacturing continues to undergo restructuring in the USA, and that wages and salaries in many sectors of these industries are higher than the USA average. He found that, while energy and the environment present many challenges, addressing these challenges also represents potential opportunity. Existing sustainable energy industries will have to greatly expand, new industries will have to develop, and rapidly growing sustainable energy industries can be a major part of a new American industrial revolution engendered by the need to address climate issues and related challenges.

In 2018, Kuralbayeva found that there are 10.3 million renewable energy jobs 
globally-a 5.3\% increase since 2017 (Kuralbayeva, 2018). She also found that USA renewable energy employment is growing: during 2016, the solar workforce increased by $25 \%$ and wind energy jobs increased by $32 \%$. However, this only included the energy and electricity-generation sectors. In the USA, the electricity-generation sector is relatively small $-5 \%$ of the total workforce. She estimated how many green jobs there are in the rest of the USA workforce and, for those jobs which are not green, how the transition to a low-carbon economy could affect them. She found that $1.2 \%$ of USA jobs are unique to the green economy. On average, $59.4 \%$ of the tasks involved in these jobs are "green tasks" while another $9.1 \%$ of the workforce performs some green tasks. On average, $30.4 \%$ of the tasks carried out in these jobs are green. When she included all jobs in which workers are currently undertaking at least one green task, she estimated that $10.3 \%$ of USA jobs are "green." She determined that a further $9.1 \%$ of the USA workforce is in jobs which will be necessary to support the green economy but which do not directly support green tasks.

In 2019, E2 found that in every USA region, clean energy is creating jobs (E2, 2019). Nationwide, more than 110,000 new clean energy jobs were created in 2018, bringing the total number of Americans working in clean energy to 3.26 million. While jobs in solar declined, wind energy jobs grew by nearly $4 \%$. Energy efficiency continues to lead the clean energy sector in total number of jobs, growing $3.4 \%$ to 2.3 million jobs. Driven by growing consumer demand, the number of jobs in clean vehicles manufacturing increased by $16 \%$. About 254,000 Americans now work at companies building hybrid, electric, and other clean vehicles, while another 486,000 work in companies that manufacture parts that make vehicles more efficient. Energy storage saw a $14 \%$ increase, while grid modernization jobs grew by $3.3 \%$. State policies continue to drive much of the growth in clean energy jobs.

In 2018 Bowen, Kuralbayeva, and Tipoec estimated the share of USA jobs that would benefit from a transition to the green economy, and presented different measures for the ease with which workers are likely to be able to move from non-green to green jobs (Bowen, Kuralbayeva, \& Tipoec, 2018). They found that $19.4 \%$ of USA workers are currently part of the green economy in a broad sense, although a large proportion of green employment is indirectly green. Green jobs vary in "greenness," with few jobs consisting only of green tasks, suggesting that "green" should be considered a continuum rather than a binary characteristic. While it is easier to transition to indirectly green rather than directly green jobs, greening is likely to involve transitions on a similar scale and scope of existing job transitions. Non-green jobs differ from their green counterparts in only a few skill-specific aspects, suggesting that most re-training can happen on-the-job. They found that the green economy offers a large potential for short-run growth.

In 2019, Novello and Carlock recommended broadening the green job definition to include jobs related to sustainability, with a focus on the care and educational sectors (Novello \& Carlock, 2019). Implementing sustainability policy re- 
quires a definition of green jobs based on a sustainability framework, which includes good-paying jobs that contribute to the process of achieving environmental, social, and economic sustainability. In order to track progress toward a sustainable economy, federal action is required to measure green jobs. They cannot be measured without standardized survey data, and the authors recommended that Congress reauthorize funding for the BLS Green Goods and Services survey and that BLS clarify and expand the criteria for defining green jobs and streamline the processes for collecting this information. In addition, there must be opportunities for workers to access job training pathways toward jobs that have at least the same salary, in order to encourage workers to move into green jobs. The green job component of the GND aims to address issues of low wages and unemployment by providing training and good jobs. A federally funded and locally administered job guarantee program would allow localities to address systemic inequalities in the labor market and in green infrastructure.

In 2019, Georgeson and Maslin noted that the green economy has been defined and measured in various ways, and they estimated employment in the USA Green Economy (Georgeson \& Maslin, 2019). They contended that this can indicate the green economy's role in economic development and employment at the county level. It also makes it possible to compare the scale of "green jobs" to employment in fossil fuel-related sectors, and to compare the USA green economy to others. Using the Low Carbon and Environmental Goods and Services Sector dataset, they estimated that the USA green economy represents $\$ 1.3$ trillion in annual sales revenue and employs 9.5 million workers; both of which have grown by over $20 \%$ between 2012/13 and 2015/16. Comparison with China, OECD members, and the G20 countries suggests that the USA has a greater proportion of the working age population employed (4\%) and higher sales revenue per capita in the green economy. The USA should consider developing energy, environmental, and educational policies relevant to the green economy to remain competitive.

In 2019, Brown and Ahmadi claimed that the GND offers a vision of how the economy could advance from traditional fossil-fuel dependence to a low-carbon future (Brown \& Ahmadi, 2019). Their analysis indicated that a cleaner-energy approach motivated by carbon taxes would promote innovation, open new markets, and increase jobs. They contended that USA clean-energy technologies struggle to compete because fossil energy is so "inexpensive." Their analysis showed that raising energy prices would empower the transition to efficiency, renewables, and other low-carbon resources. A carbon tax of $\$ 25$ or $\$ 60$ would cut carbon emissions significantly, but the higher tax would produce quicker and deeper reductions. While both tax levels would grow jobs, the \$25 tax would provide more employment growth than the $\$ 60$ one. Their analysis suggested that a low-carbon economy is likely to be a stronger and more secure economy that also provides climate solutions. They estimated that the $\$ 25$ carbon tax would increase USA employment by 1.4 million jobs annually between 2020 and 2030 - a $1 \%$ increase above the reference case forecast. As the economy expands 
and the tax increases, job growth from the GND would accelerate, 3.4 million new jobs each year between 2040 and 2050-a 2\% increase above the reference forecast. They estimated that 72 million job years would be created over three decades with a $\$ 25$ carbon tax.

\section{Defining Green Jobs and GND Jobs}

What exactly constitutes a "green job?" While a definitive analysis of this term is outside the scope of this report, our review of the literature indicates that there is no rigorous, well-accepted definition of a green job. Rather, the definitions used are often loose and contradictory.

Measuring green jobs is difficult because the traditional method of understanding, estimating, and classifying trends in the labor market is through the categories of industry and occupation, which do not have a category for "green." Green jobs pose an especially difficult problem in this context, as the GUCEW noted: "The greenness of jobs even within a single occupation will vary according to the nature of the firm or establishment, the current project or specific work assignment, and the specific employer's workplace rules and policies. Thus, labor market analysts cannot merely count all employees in a particular occupation (much less in an entire industry) as green collar workers" (Georgetown University Center on Education and the Workforce, 2011).

Clearly, an ecologist, a solar panel installer, a hydrogen specialist, or an environmental engineer would constitute a green job, as would an employee of a federal or state renewable energy agency or of an environmental protection agency. However, there are ambiguities. For example, most people would agree that the positions in a firm that assembles and installs solar collectors would be considered green jobs. But what about the jobs involved in producing those solar panels, especially if the factory involved used coal-based energy, one of the most controversial fossil fuels in terms of emissions? Here these manufacturing jobs are included as jobs created indirectly by green energy expenditures.

Most analysts would consider jobs in a recycling plant to be green jobs. But what if the recycling plant itself produces air pollution? What about a firm in Illinois that produces emissions control equipment for power plants in Georgia? It seems clear that the jobs in the Illinois company should be considered green jobs, even though the user of the equipment in Georgia may cause pollution in several states. What about environmental engineers and environmental controls specialists working in a coal-fired power plant? What about the workers who produce environmental control equipment for the power plant?

Concerns about potential climate change driven by rising atmospheric concentrations of greenhouse gasses (GHGs) have increased over the past two decades. In the USA, policies to limit GHG emissions are in various stages of development at the state, regional, and federal levels. Analysts and policy-makers have realized that any ambitious decarbonization goals are simply not feasible without carbon capture, utilization, and storage (CCUS). Even many environmentalists and GND advocates have (grudgingly) accepted the need for CCUS as 
a necessarily large part of any future $\mathrm{CO}_{2}$ reduction programs. The simple fact is that any ambitious decarbonization will require massive amounts of CCUS, and any $\mathrm{CO}_{2}$ stabilization or reduction is impossible without CCUS. So, are CCUS jobs considered to be green jobs? What about CCUS jobs that also involve the use of the captured $\mathrm{CO}_{2}$ for enhanced oil recovery?

There are many firms in the USA that produce products for the automotive industry. Should those that produce components for fuel-efficient vehicles be considered part of the green industry, but not those that produce components for gas guzzlers? If so, is there any way to accurately distinguish between these? Should all factories producing catalytic converters be considered green jobs, even when some of these converters are used on low miles-per-gallon vehicles? What about the jobs producing massive concrete bases for offshore wind installations? The concrete industry is one of the largest producers of GHGs.

These questions have, in fact, been generated by shifts in energy and environmental policy itself. The early stages of the renewable energy and environmental movement in the 1970 s and 1980 s focused primarily on "end-of-the pipe" solutions: the remedies focused on cleaning or minimizing air, water, or solid waste pollutants after they had been produced. However, environmental protection has evolved to include entire processes, so, rather than cleaning up at the end of the pipe, entire manufacturing and servicing processes are being designed to minimize the production of pollutants. Therefore, it is possible that efficient processes designed to produce relatively little waste output could actually result in a decrease in the number of "green" jobs if these are defined strictly as "end of the pipe" jobs. Renewable energy and energy efficiency have resulted in less need for electric power and have caused the closure of coal-fired power plants. While some may view such a shutdown as an environmental and green energy plus, many environmental "green" jobs in the power plants involving pollution abatement and control are being lost.

While solid waste abatement is a major area of environmental concern, does this imply that all persons engaged in trash collection are performing green jobs? What part of the tourism industry constitutes "ecotourism," and are all jobs associated with ecotourism green jobs? Are alternative energy green industries, with all jobs counting as green jobs? The recent controversial documentary film Planet of the Humans contends that virtually no renewable energy jobs are really "green" (Bradshaw, 2020).

There is also the issue of how to account for indirect job creation and how broadly or narrowly to define an indirect green job. For example, what of ancillary jobs created near a factory producing solar collectors, such as those in restaurants, dry cleaners, etc. whose customers are primarily the workers at the factory. Are these latter jobs also considered to be "indirect" green jobs? We include such indirect jobs in our definition of green jobs.

More generally, we consider that jobs can be considered to be "green" relative to the way the job was performed previously, i.e., in a production process, a change in technology that reduces waste emissions or energy consumption 
makes the jobs in that process "greener" than before. Based on extensive research and literature review, we determine that green jobs are best understood when viewed in a continuum, with jobs that generate environmental degradation or extraction at one end; a range of greener jobs involving renewable energy, clean production measures, and environmental technologies in the center, and the other end of the spectrum where jobs have a positive green impact (see Figure 1). Using this concept, we define green industries and green jobs as those which, as a result of energy and environmental concerns, produce the products, processes, and services which specifically produce renewable energy or target the reduction of environmental impacts. Green jobs include those created both directly and indirectly by renewable energy, energy efficiency, and environmental protection expenditures. The jobs include those created both directly and indirectly in the USA by the GND.

There exists relatively little rigorous research addressing the practical relationship between green energy, environmental protection, and job creation. Even some research in this area sponsored by renewable energy and environmental organizations is misguided, in that it has tended to emphasize jobs creation in classically green activities, such as environmental lawyers or workers in solar energy facilities. However, while these jobs count as green jobs, we have found that classic green jobs constitute only a small portion of the green jobs created. The vast majority of green jobs are standard jobs for accountants, engineers, computer analysts, clerks, factory workers, truck drivers, mechanics, etc. In fact, most of the persons employed in these jobs may not even realize that they owe their livelihood to green energy and environmental protection. This issue is discussed further in Section 5.

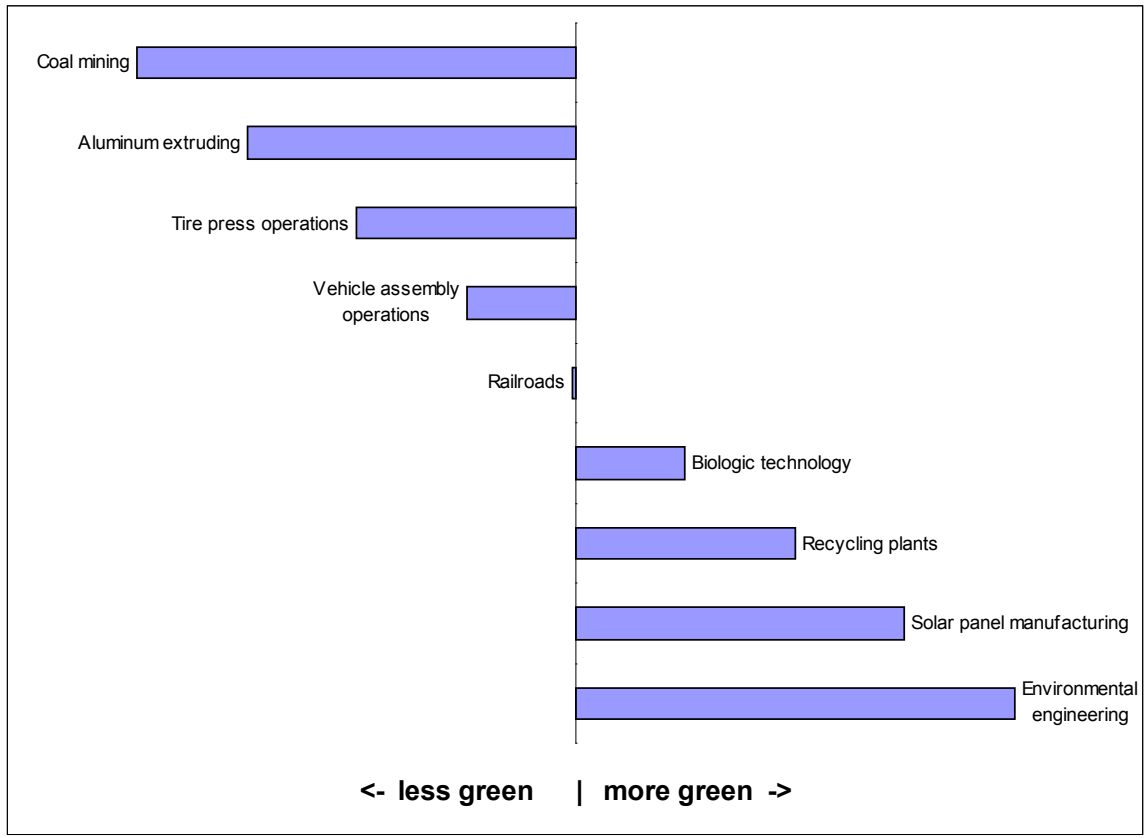

Figure 1. The green job spectrum. Source: Management Information Services, Inc. 
More generally, arguments stressing the economic benefits and job creation resulting from green energy initiatives are not currently being made in a rigorous manner which disaggregates these benefits to a level of detail meaningful to policymakers. The level of detail required is at the sector, industry, state, city, and county level, and the green jobs created have to be identified by industry, category, skill, and specific occupation at the state and local level. The findings presented here facilitate the provision of data at such levels of detail.

\section{Methodology}

In its GND and green jobs studies, MISI uses the employment concept of a full time equivalent (FTE) job and defines a "job" as an FTE job in the USA. An FTE job is defined as 2,080 hours worked in a year's time, and adjusts for part time and seasonal employment and for labor turnover (Eurosatat, 2020). For example, two workers each working six months of the year would be counted as one FTE job. An FTE job assessment allows meaningful comparisons over time and across jurisdictions, since it consistently measures the input of labor in the production process and is the standard that should be followed in employment analyses (Eurosatat, 2020).

Thus, a "job" created is defined as an FTE job created for one person for one year, and 50,000 jobs created will refer to 50,000 persons employed for one year. It is correct to state that "over a ten year period 500,000 cumulative jobs are created" as long as it is specified that this refers to 50,000 persons, each employed annually for 10 years.

MISI also estimates direct, indirect, and induced jobs:

- Direct jobs are those created directly in the specific activity or process.

- Indirect jobs are those created throughout the required interindustry supply chain.

- Induced jobs are those created in supporting or peripheral activities.

- Total jobs are the sum or all of the jobs created.

For simplicity, MISI includes induced jobs in the indirect category.

MISI estimated the total (direct, indirect, and induced) jobs created by the GND (Management Information Services, Inc., 2009; Bezdek \& Wendling, 2013; Bezdek, 2008).

The total (direct, indirect, and induced) jobs concept is the accepted methodology widely used in studies of this nature and in the peer-reviewed literature.

In estimating the impacts on the entire labor market, it is thus important to recognize that one lost dollar of economic output or one lost job is not the same as another. Each industry has backward linkages to economic sectors that provide the materials needed for the industry's output, and each industry also has forward linkages to the economic sectors where the industry's workers spend their income. Therefore, in addition to the jobs directly supported by an industry, a large number of indirect jobs may also be supported by that industry. The inclusion (or exclusion) of jobs and output in industries with strong backward 
and forward linkages to other economic sectors can cause indirect and induced impacts. Employment multipliers measure how the creation or destruction of output or employment in a particular industry translates into wider employment changes throughout the economy (Understanding Multipliers, 2020).

The economic and employment effects of the GND were estimated using the Management Information Services, Inc. (MISI) model, database, and information system. A simplified version of the MISI model as applied here is shown in Figure 2.

The first step involves translation of GND expenditures into per unit output requirements from every industry in the economy. Second, the direct output requirements of every industry affected by the expenditures are estimated, and they reflect the production and technology requirements implied by the GND spending. These direct requirements show, proportionately, how much an industry must purchase from every other industry to produce one unit of output. Direct requirements, however, give rise to subsequent rounds of indirect requirements. The sum of the direct plus the indirect requirements represents the total output requirements from an industry necessary to produce one unit of output.

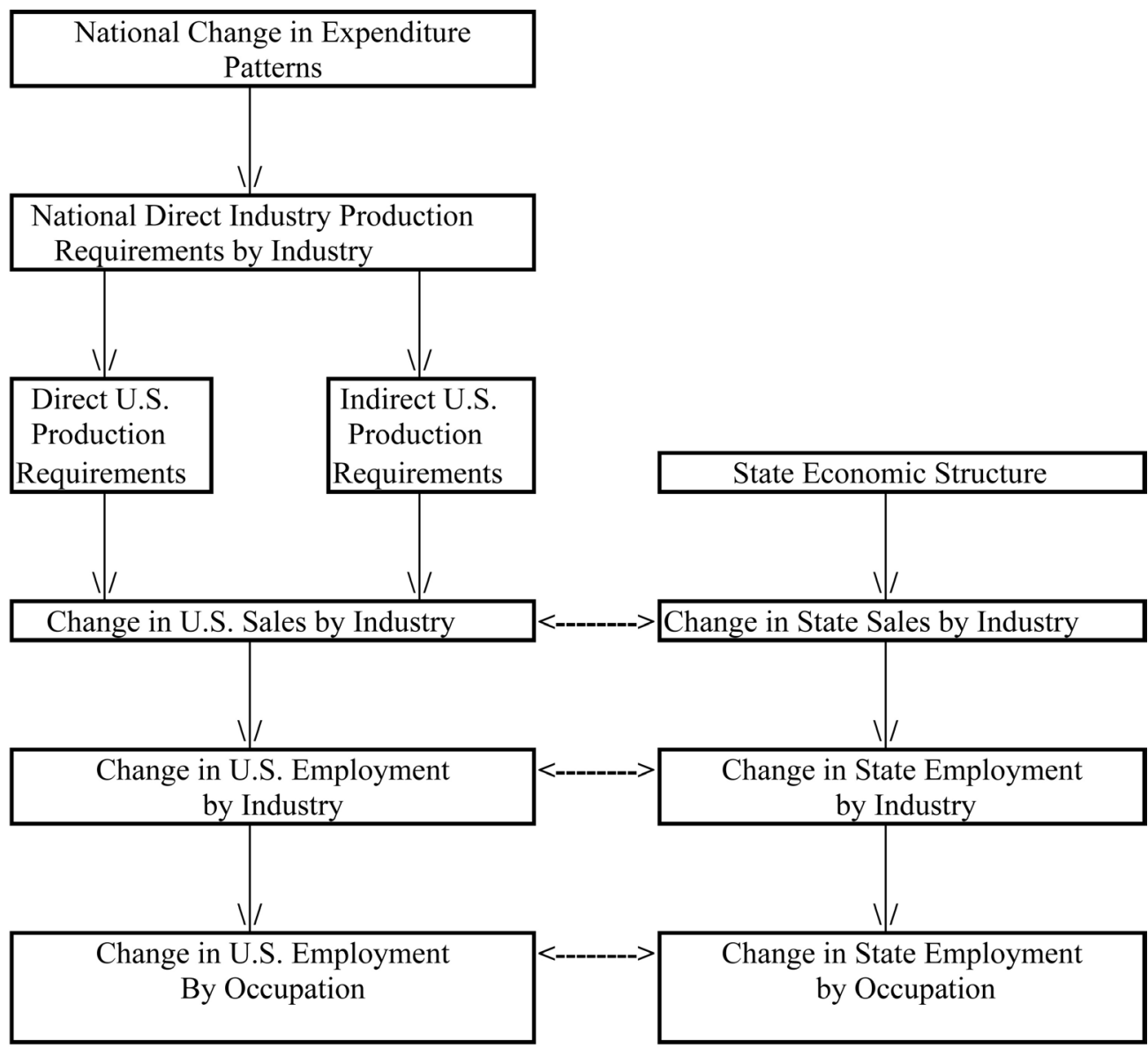

Figure 2. Use of the MISI model to estimate GND Job impacts. Source: Management Information Services, Inc. 
Economic input-output (I-O) techniques allow computation of the direct and the indirect production requirements. Direct industry output requirements are converted into total output requirements from every industry by means of the input-output inverse equations. These equations show not only the direct requirements, but also the second, third, fourth, nth round indirect industry and service sector requirements resulting from GND expenditures. Next, the total output requirements from each industry are used to compute sales volumes, profits, and value added for each industry. Then, using data on man-hours, labor requirements, productivity, and employment requirements, the numbers of jobs created within each industry are estimated.

The next step requires conversion of total employment requirements by industry into job requirements for specific occupations and skills. To accomplish this, MISI utilizes data on the occupational composition of the labor force within each industry and estimates job requirements for 700 occupations encompassing the entire USA labor force. This permits estimation of the impact of the GND on jobs for specific occupations.

Utilizing the modeling approach outlined above, the MISI model allows estimation of the effects on employment, personal income, corporate sales and profits, and government tax revenues in the USA. Estimates of these can then be developed for detailed industries and occupations.

The final step in the analysis requires assessing the economic impacts on individual states, which can be estimated using the MISI regional model, which allows the flexibility of specifying multi-state, state, or county levels of detail. Because of the comprehensive nature of the modeling system, these regional impacts are consistent with impacts at the national level.

\section{Findings}

Contrary to general public perception and public policy understanding, in recent decades, green energy and environmental protection have grown rapidly to become a major sales-generating, profit-making, job-creating industry. The size and the job creating potential of the green industry is something that few people are aware of. MISI estimates that in 2019, USA green jobs (direct plus indirect) totaled about 7.8 million. In the USA, MISI estimates that the green "industry" currently ranks above the top of the Fortune 500 (Fortune, 2020) and MISI estimates that in 2019 the green industry generated:

- $\$ 640$ billion in total industry sales

- 7.8 million jobs

For perspective, compared the revenues generated by other industries, this is (U.S. Bureau of Labor Statistics, 2020; U.S. Bureau of Economic Analysis, 2020):

- About equal to all supermarkets and grocery stores

- Greater than the construction industry

- More than twice the size of the mining industry

- $25 \%$ greater than Walmart 
- Twice the size of ExxonMobil

- More than 2.5 times the size of Apple

- 2.75 times the size of Amazon

- Four times the size of Ford

Thus, the green industry is currently a major factor in the USA economy and job market. The question here is what impact the GND would have. The GND is not well defined and there are many different versions, and the GND cost has been estimated at anywhere from $\$ 2$ trillion to $\$ 6$ trillion-and higher (Lewis, 2019; Whyte, 2019; Kusnetz, 2019). MISI estimates that the GND would cost about cost about $\$ 2.5$ trillion in expenditures (2019 dollars) and would generate more than 18.3 million jobs (direct plus indirect). Thus, here MISI is using a relatively modest version of the GND costing about $\$ 2.5$ trillion that is concerned primarily with energy and environmental programs. As noted, some versions of the GND also include a variety of health, education, and other social policies. Of course, the economic and job impacts of the GND will differ depending on the size, structure, and duration of the GND specified.

The 18.3 million jobs estimated is a very large number. However, it is sobering to note that in the eight week period from early March to early April 2020, about 36.5 million Americans filed for unemployment insurance, with weekly totals above three million a week. Thus, the 18.3 million jobs is only half as many jobs as were lost in an eight week period. The official USA April 2020 unemployment rate of $14.7 \%$ actually underestimated the current degree of joblessness. The regular unemployment rate excludes so-called discouraged workers-those who are not actively looking for work. In addition, it is based on surveys conducted in second week of April, and many more workers lost their jobs in the latter half of the month. Further, many self-employed workers, gig workers, and others are not included in the $14.7 \%$ estimate. Finally, many unemployed workers have been unable to file unemployment claims: Unemployment benefits are administered by states, and many state systems are simply overwhelmed (Chaney \& Morath, 2020). Given the undercount of the unemployed, it is likely that the actual USA unemployment rate in May 2020 was at least 25\%-a level of joblessness not seen since the Great Depression of the1930s.

MISI also estimated the jobs in the manufacturing sector that would be generated by the GND. Of the 18.3 million jobs, about 2.25 million would be "green" manufacturing jobs. A disaggregation of some of the major industrial components of these jobs-by 2 and 3 digit North American Industrial Classification System (NAICS) Code-is presented in Table 1.

Examining the GND jobs generated by industry indicates that the impact is distributed across the economy (Table 1). The industries involved are not surprising given the parts they will play in the evolving transformation to a new green energy economy and subsequent economic growth. Some of the industries showing the largest jobs impacts are listed in order with the part they will play in the GND: 
Table 1. Jobs by select industry resulting from the GDN in 2030.

\begin{tabular}{|c|c|}
\hline Industry Title & Jobs (thousands) \\
\hline \multicolumn{2}{|l|}{ Select Manufacturing Industries } \\
\hline Electrical equipment, appliances, and components & 230 \\
\hline Miscellaneous manufacturing & 225 \\
\hline Fabricated metal products & 200 \\
\hline Nonmetallic mineral products & 195 \\
\hline Motor vehicles, bodies and trailers, and parts & 115 \\
\hline Primary metals & 95 \\
\hline Chemical products & 90 \\
\hline Other transportation equipment & 80 \\
\hline Computer and electronic products & 50 \\
\hline Machinery & 45 \\
\hline Plastics and rubber products & 40 \\
\hline Wood products & 35 \\
\hline Paper products & 30 \\
\hline Textile mills and textile product mills & 20 \\
\hline \multicolumn{2}{|l|}{ Other Select Industries } \\
\hline Construction & 960 \\
\hline Miscellaneous professional, scientific and technical services & 350 \\
\hline Waste management and remediation services & 230 \\
\hline Utilities & 145 \\
\hline Information and data processing services & 105 \\
\hline Computer systems design and related services & 100 \\
\hline Total Jobs (including industries not listed separately) & 18,340 \\
\hline
\end{tabular}

Source: Management Information Services, Inc.

- Construction-the industry receives an overwhelming direct stimulus from GND expenditures in addition to a positive indirect impact from improvement in overall economic growth due to energy savings.

- Professional, scientific, and technical services-the industry and its employees play a large part in driving the new green energy technologies.

- Waste management and remediation services-the industry will play a major role in energy efficiency and in supplying biogas.

- Electrical equipment, appliances, and components-the industry will be relied upon to supply not only new electrical components and testing equipment to all the green electric energy technologies, but will also facilitate efficiencies in the smart grid from generation to final consumer use.

- Miscellaneous manufacturing-manufacturing growth will require the industry's output, and it is indirectly stimulated by overall economic growth. 
- Fabricated metal products-the industry will be the primary supplier of parts, products, and systems for the photovoltaic, wind, concentrating solar, and other green technologies.

- Nonmetallic mineral products-the industry supplies two major products that will be in high demand in several green technologies: Glass and fiberglass.

- Utilities-electric and gas energy supply transitions to green technologies, and the industry will also be stimulated by various energy efficiency initiatives.

- Motor vehicles, bodies and trailers, and parts-the industry will be augmented by green energy transportation improvements that stimulate R\&D and vehicle sales as the USA rolling stock turns over.

- Computer systems design and related services-the industry will be stimulated by the smart grid and other green applications.

- Primary metals-as supplier of metal for finished products, this industry will be indirectly impacted by increased demand from other manufacturing industries.

- Chemical products-the industry will benefit from the growth of biofuels and biomass.

- Other transportation equipment-transportation energy efficiency improvements will impact this industry.

MISI also found that the GND jobs are concentrated within a number of sectors, including manufacturing and professional, information, scientific, and technical services. This is significant because the USA and numerous states are seeking to expand their high-tech industrial and manufacturing bases. Thus, not only is the relationship between the GND and jobs positive, but the types of jobs created are disproportionately scientific, professional, technical, high-skilled, manufacturing, and high-wage jobs-the very types of jobs that all states wish to attract. These types of jobs are a prerequisite for a prosperous, middle class society able to support state and local governments with tax revenues-which states clearly recognize. Of particular note, MISI estimates that the GND will provide a greater than proportionate assist to the manufacturing sector.

The vast majority of the millions of jobs created by the GND are standard jobs for accountants, engineers, computer analysts, clerks, factory workers, truck drivers, etc., and classic green jobs (photovoltaic engineer, ecologist, fuel cell technician, etc.) constitute only a small portion of the jobs created. In fact, most of the persons employed in the jobs created may not even realize that they owe their livelihood to the GND.

This finding is important for, even recognizing that the GND is beneficial for the economy and is creating millions of jobs, the first impression is likely that these are jobs for green energy specialists, solar installers, environmental regulators, etc. MISI determined that jobs for all occupations and skills are generated, and this should be of interest to policy-makers, organized labor, and trade and professional associations. 
For example, MISI estimates that the GND will create:

- More jobs for sheet metal workers than for geoscientists

- More jobs for electricians than for chemists

- More jobs for computer software engineers than for hazardous material removal workers

- More jobs for machinists than for forest and conservation technicians

- More jobs for welders than for biochemists

- More jobs for plumbers than for health and safety engineers

- More jobs for security guards than for ecologists

- More jobs for janitors than for natural science managers

- More jobs for financial managers than for conservation scientists

- More jobs for executive secretaries than for hydrogen technicians

- More jobs for truck drivers than for fuel cell researchers

- More jobs for human resource managers than for environmental scientists

- More jobs for stock clerks than for chemists

- More jobs for management analysts than for foresters

Unlike some industries, green industries and GND jobs are feasible targets for job creation in many states and regions. With a wide diversity of required skills and continuing research into relevant technologies, communities can develop clusters around different sectors of the industries. However, states and cities must recognize that they will be in intense competition as communities throughout the USA compete for these emerging technologies and industries with traditional university-centered research areas, including Palo Alto (Stanford University), Ann Arbor (University of Michigan), Trenton (Princeton University), Boston (MIT), Champaign-Urbana (University of Illinois), Austin (University of Texas), the Research Triangle in North Carolina, and other university-industry complexes. In addition, communities must compete for these jobs with traditional high-tech metropolitan areas like San Jose, Boston, and Washington D.C., along with metropolitan areas with rapidly expanding manufacturing, such as Grand Rapids, Michigan, Denver, Colorado, and Portland, Oregon.

However, numerous GND jobs will be created in all USA metropolitan areas. These area green economies can be categorized into four types: Service-oriented, manufacturing, public sector, and balanced. New York, through mass transit, embodies a service orientation, as does San Francisco through professional services and Las Vegas through architectural services. Many Midwestern and Southern areas, such as Louisville, Cleveland, Greenville, SC, and Little Rock-as well as San Jose in the West-have green economies that are heavily manufacturing oriented. State capitals are among those with a disproportionate share of green jobs in the public sector (e.g. Harrisburg, Sacramento, Raleigh, and Springfield). Finally, some metropolitan areas, such as Atlanta, Salt Lake City, Portland, OR, and Los Angeles, possess multi-dimensional green economies. Further, the GND will create large numbers of jobs in professional environmental services in Houston, in photovoltaics in Los Angeles, fuel cells in Boston, and 
wind energy in Chicago.

GND jobs will be created across a new continuum of employment, skills, responsibilities, and earnings. Notably, many of these jobs do not currently exist and do not have occupational titles defined in federal or state government occupational handbooks and employment guides. Further, many of these new jobs require different skills and education than current jobs, and training needs must be assessed to enable this rapidly growing sector of the USA economy and labor market to have a sufficient supply of trained employees. Eventually, most of these occupations will grow, the number of employees classified in the occupations will increase, and federal and state governments will add them to their employment classifications. Until then, labor market and employment analysis and forecasting will be performed using the current set of USA Labor Department occupational titles and job descriptions. In the meantime, we have developed the methodology and database discussed here.

\section{Conclusion}

The GND in the USA will lead to numerous jobs and vast new employment opportunities as businesses expand to serve growing markets and to meet new green energy requirements and mandates. We find that green industries will create a variety of new high-paying jobs, many of which take advantage of technical and manufacturing skills currently going unused as industry continues to undergo restructuring, and USA states, regions, and cities can recruit these emerging industries and companies.

Although many high-tech industries almost exclusively require highly educated workers with advanced degrees, as noted, the green industries possess requirements for numerous types of occupations, experience, and skills. Many occupations in these industries include jobs which require associate degrees, on-the-job training, or trade certifications, including scientists, engineers, chemists, managers, and technicians, all of which pay higher than average USA wages. Unlike some industries, green industries are a realistic target industry for job creation in most regions and states. Communities can build clusters around different segments of the industries, and the wide variety of entrance points to the green industries makes this market easier to penetrate if regions can market their strengths in high-tech, research, education, manufacturing, IT, green technologies, and energy.

Nevertheless, challenges remain, and our work has identified several areas requiring further research. First, a more rigorous and generally accepted definition of what constitutes a "green job" is required. GND advocates and green energy promoters tend to identify the more glamorous types of jobs, such as ecologist, renewable energy engineer, wildlife biologist, fuel cell researcher, solar energy installer, etc., but the overwhelming majority of green jobs are for standard occupations, skills, and professions. Nevertheless, the numbers and types of green jobs-both in general and in specific industries and firms-require additional 
research.

Second, the empirical work reported here needs to be expanded to the state and regional level. While we have estimated GND jobs at the national level, much more detailed assessment of green jobs at the sub-national level is required. Such an assessment would also look in detail below the state level to specific geographic regions and industries and conduct in-depth analyses of specific green firms. It really does come down to "jobs, jobs, jobs!" It is impossible to over-emphasize the importance of jobs impacts-especially in the current environment of record unemployment. Regional disaggregation is required of the GND jobs created, especially at the state level of detail, and below. There is great Congressional and state and local government decision-maker interest in these data and there will be a large and influential audience for the estimates. The implications of determining the benefits to specific states and regions are obvious, for the debate at the state and regional level inevitably revolves around jobs.

Third, the number of GND jobs created is important, but it is also important to disaggregate the employment generated into industries, occupations, and skills. From previous MISI work it is clear that green jobs generated are disproportionately concentrated in fields related to the construction, energy, utilities, technology, industrial, and related sectors, reflecting the requirements of the GND programs and their supporting industries. The green jobs created are across a wide spectrum in many industries and in professional and skilled occupations. However, it is also true that numerous jobs are also being created at all skill levels. Accordingly, the importance of jobs in some occupations is much greater than in others, and further research is required to estimate these occupation/skill impacts more definitively. The detailed indirect green jobs impacts by sector, industry, and occupation/skills, as well as new and emerging occupations, need to be estimated. MISI research indicates that many of the jobs generated are in industries and occupations not necessarily linked to green industries and are, instead, created throughout the interindustry supply chain and in supporting activities (Bezdek \& Wendling, 2015; Bezdek \& Wendling, 2014a). While some illustrative examples of these have been reported here, this issue requires rigorous research.

Fourth, it would be useful to have international perspective. We found that in the USA, the GND would create about 18.3 million jobs. Using generally consistent concepts and definitions, it would be useful to determine how these estimates compare to estimates of the jobs that would be created by GND-type initiatives in other nations. International comparative analyses of detailed results at the sectoral, industrial, and occupational level are especially germane.

Finally, forecasts of GND jobs have to be further refined to estimate the number of jobs openings that will occur, the types of jobs created, when they will occur, and where they will be located. Training for new skills will be needed across a wide spectrum of industries (Bezdek, 2019a; Bezdek, 2019b; Bezdek, 2013). Some changes in skills are relatively well defined, but many likely changes re- 
main difficult to forecast since green technologies are still evolving. Many job tasks currently remain unknown, and thus identification of training needs requires interactive research combined with job definition. Science and engineering education needs to prepare students for green energy jobs, and university and vocational programs need to be assessed to understand where opportunities lie and what additional curricula may be needed. Community colleges, technical schools, colleges, and universities need to be evaluated to determine how well they are preparing the workforce for the emerging green economy and labor market.

\section{Acknowledgements}

The author is grateful to an anonymous referee for comments on a previous draft of this manuscript. The opinions expressed here and any errors are the sole responsibility of the author.

\section{Conflicts of Interest}

The author declares no conflicts of interest regarding the publication of this paper.

\section{References}

Apollo Alliance (2004). New Energy for America: The Apollo Jobs Report.

Barrett, J. P., \& Hoerner, J.A. (2004). Clean Energy and Jobs: A Comprehensive Approach to Climate Change and Energy Policy. Washington DC: Economic Policy Institute.

Bernow, S., Dougherty, W., Duckworth, M., Kartha, S., \& Lazams, M. (1999). America's Global Warming Solutions. Boston, MA: Tellus Institute and Stockholm Environment Institute.

Bezdek, R. H. (2008). Renewable Energy and Energy Efficiency: Economic and Job Opportunities from Addressing Global Warming. Al Gore Climate Summit, Nashville, TN.

Bezdek, R. H. (2013). Emerging Challenges and Opportunities for the Geoscience Workforce (Keynote). The Geoscience and the 21st Century Workforce Workshop, sponsored by The National Science Foundation, Penn State University.

Bezdek, R. H. (2016). Economic and Job Forecasts for the Sustainable Energy Industries in the USA. International Journal of Engineering and Applied Sciences, 3, 50-55.

Bezdek, R. H. (2019a). The Hydrogen Economy and Jobs of the Future. Renewable Energy and Environmental Sustainability, 4, Article No.: 1. https://doi.org/10.1051/rees/2018005

Bezdek, R. H. (2019b). The Hydrogen Economy and Jobs of the Future. Presented at the 2019 Fuel Cell Seminar \& Energy Exposition, Long Beach, CA.

Bezdek, R. H., \& Wendling, R. M. (2013). Economic, Environmental, and Job Impacts of Increased Efficiency in Existing Coal-Fired Power Plants. Journal of Fusion Energy, 32, 215-220. https://doi.org/10.1007/s10894-012-9556-y

Bezdek, R. H., \& Wendling, R. M. (2014a). Chapter 4: Job Creation through Green Energy Economy. In J. Byrne, \& Y.-D. Wang (Eds.), Green Energy Economies (pp. 49-86). New Brunswick, NJ: Transaction Publishers. https://doi.org/10.4324/9780203790434-4 
Bezdek, R. H., \& Wendling, R. M. (2014b). The Jobs Impact of GHG Reduction Strategies in the USA. International Journal of Global Warming, 6, 380-401. https://doi.org/10.1504/IJGW.2014.066046

Bezdek, R. H., \& Wendling, R. M. (2015). Economic and Jobs Impacts of Enhanced Fuel Efficiency Standards for Light Duty Vehicles in the USA. International Journal of Engineering and Innovative Technology, 4, 122-135.

Bezdek, R. H., Wendling, R. M., \& DiPerna, P. (2008). Environmental Protection, the Economy, and Jobs: National and Regional Analyses. Journal of Environmental Management, 86, 63-79. https://doi.org/10.1016/j.jenvman.2006.11.028

Bowen, A., Kuralbayeva, K., \& Tipoec, E. L. (2018). Characterising Green Employment: The Impacts of "Greening" on Workforce Composition. Energy Economics, 72, 263-275. https://doi.org/10.1016/j.eneco.2018.03.015

Bradshaw, P. (2020). Planet of the Humans Review-Contrarian Eco-Doc from the Michael Moore Stable. The Guardian, April 22.

Brookings Institution (2011). Sizing the Clean Economy: A National and Regional Green Jobs Assessment. Washington DC: Brookings Institution.

Brown, A. M., \& Ahmadi, M. (2019). Would a Green New Deal Add or Kill Jobs? Scientific American, December 17.

Bruyère, S. M., \& Filiberto, D. M. (2013). The Green Economy and Job Creation: Inclusion of People with Disabilities. International Journal of Green Economics, 7, 257-275. https://doi.org/10.1504/IJGE.2013.058151

California Center for Jobs and the Economy (2015). California Green Jobs: A Review of Current Estimates.

Chaney, S., \& Morath, E. (2020). April Unemployment Rate Rose to a Record 14.7\%. Wall Street Journal, May 8.

E2 (2019). Clean Jobs America: Nearly 3.3 Million Clean Energy Jobs. http://www.cleanjobscount.org/

Eurostat (2020). https://web.archive.org/web/20120928112059/ http://epp.eurostat.ec.europa.eu/statistics_explained/index.php/Glossary:Full-timeequi valent

Fortune (2020). https://fortune.com/fortune500/

Georgeson, L., \& Maslin, M. (2019). Estimating the Scale of the US Green Economy within the Global Context. Palgrave Communications, 5, Article No.: 121. https://doi.org/10.1057/s41599-019-0329-3

Georgetown University Center on Education and the Workforce (2011). State of Green: The Definition and Measurement of Green Jobs. Washington DC: Georgetown University Center on Education and the Workforce.

Kuralbayeva, K. (2018). How Many Green Jobs Are There in the US? Grantham Research Institute on Climate Change and the Environment, London School of Economics.

Kusnetz, N. (2019). Sanders Unveils \$16 Trillion Green New Deal Plan, and Ideas to Pay for It. InsideClimate News, August 22.

Lewis, M. (2019). How Much Will the Green New Deal Cost Your Family? Washington DC: Competitive Enterprise Institute.

Management Information Services, Inc. (2009). Development of Economic and Job Impacts Analysis Tool and Technology Deployment Scenario Analysis. U.S. Department of Energy, National Energy Technology Laboratory, DOE/NETL-402/092509. 
National Association of State Energy Officials and Energy Futures Initiative (2020). U.S. Energy and Employment Report. Washington DC: National Association of State Energy Officials and Energy Futures Initiative.

Novello, A., \& Greg Carlock, G. (2019). Redefining Green Jobs for a Sustainable Economy. The Century Foundation.

Regional Economics Applications Laboratory (2002). Job Jolt: The Economic Impacts of Repowering the Midwest. Chicago, IL: University of Illinois.

U.S. Bureau of Economic Analysis (2020). https://www.bea.gov/data/employment/employment-by-industry

U.S. Bureau of Labor Statistics (2020). https://www.bls.gov/web/empsit/ceshighlights.pdf https://www.bls.gov/emp/tables/employment-by-major-industry-sector.htm

Understanding Multipliers. https://implanhelp.zendesk.com/hc/en-us/articles/115009505707-Understanding-Multi pliers

Union of Concerned Scientists (2004). A 20 Percent National Renewable Electricity Standard Will Create Jobs and Save Consumers Money. Cambridge, MA: Union of Concerned Scientists.

Whyte, C. (2019). Green New Deal Proposal Includes Free Higher Education and Fair Pay. Environment, February 12. 